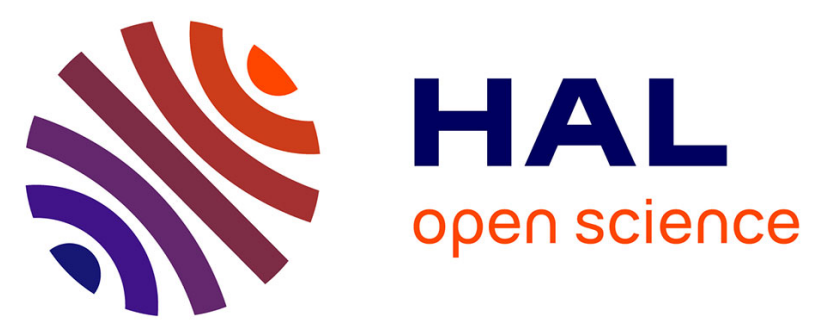

\title{
Synthesis and Characterization of Fluorescent and Photoactivatable MIP-1 alpha Ligands and Interactions with Chemokine Receptors CCR1 and CCR5
}

\author{
Sannah Zoffmann, Gerardo Turcatti, Jean-Luc Galzi, Mads Dahl, André
}

Chollet

\section{To cite this version:}

Sannah Zoffmann, Gerardo Turcatti, Jean-Luc Galzi, Mads Dahl, André Chollet. Synthesis and Characterization of Fluorescent and Photoactivatable MIP-1 alpha Ligands and Interactions with Chemokine Receptors CCR1 and CCR5. Journal of Medicinal Chemistry, 2001, 44 (2), pp.215-222. 10.1021/jm000982i . hal-02196792

\section{HAL Id: hal-02196792 \\ https://hal.science/hal-02196792}

Submitted on 29 Jul 2019

HAL is a multi-disciplinary open access archive for the deposit and dissemination of scientific research documents, whether they are published or not. The documents may come from teaching and research institutions in France or abroad, or from public or private research centers.
L'archive ouverte pluridisciplinaire HAL, est destinée au dépôt et à la diffusion de documents scientifiques de niveau recherche, publiés ou non, émanant des établissements d'enseignement et de recherche français ou étrangers, des laboratoires publics ou privés. 


\title{
Synthesis and Characterization of Fluorescent and Photoactivatable MIP-1 $\alpha$ Ligands and Interactions with Chemokine Receptors CCR 1 and CCR 5 \$
}

\author{
Sannah Zoffmann, ${ }^{\ddagger}$ Gerardo Turcatti, ${ }^{\dagger}$ J ean-Luc Galzi, ${ }^{\ddagger}$ Mads Dahl, ${ }^{*}$ and André Chollet*,† \\ Serono Pharmaceutical Research Institute, 14 chemin des Aulx, CH-1228 Plan-les-Ouates, Geneva, Switzerland, and \\ Département Récepteurs et Protéines Membranaires, CNRS UPR 9050, Ecole Supérieure de Biotechnologie de Strasbourg, \\ Bd Sébastien Brant, F-67400 IIIkirch, France
}

Received May 10, 2000

\begin{abstract}
Photoaffinity and fluorescent analogues of the 70-amino acid chemokine macrophage inflammatory protein-1 $\alpha$ (MIP-1 $\alpha$ ) were designed, synthesized, characterized, and applied to probe MIP-1 $\alpha$ interactions with the chemokine receptors CCR 1 and CCR5. The photoactivatable MIP$1 \alpha$ ligand, BP-MIP- $1 \alpha$, and the fluorescent ligand, Flu-MIP-1 $\alpha$ were prepared by selective chemical coupling of p-benzoylphenylthiocarbamyl or fluor esceinthiocarbamyl, respectively, at the N-terminus of MIP-1 $\alpha$. Both ligands BP-MIP- $1 \alpha$ and Flu-MIP-1 $\alpha$ retained high binding affinity and agonist potency at CCR1 and CCR5. Photoaffinity labeling of CCR1 and CCR5 receptors stably expressed in $\mathrm{CHO}$ cells resulted in specific covalent attachment of [125] ]BPMIP- $1 \alpha$ and production of protein complexes of 54 and $48 \mathrm{kDa}$, respectively, on SDS-PAGE. This represents the first photo-cross-linking between a chemokine and its receptor. Flu-MIP$1 \alpha$ selectively labeled CCR 1 or CCR5 receptors expressed in CHO cells and was used to characterize receptor binding domains. When bound to CCR1 or CCR5 receptors, the fluorescence signal of Flu-MIP-1 $\alpha$ was quenched by collision with iodide indicating that the $\mathrm{N}$-terminal end of MIP-1 $\alpha$ is accessible to the solvent. These data strongly suggest that the $\mathrm{N}$-terminal end of MIP-1 $\alpha$ interacts with domains of CCR 1 or CCR5 receptors located at the extracellular surface. The photoactivatable BP-MIP-1 $\alpha$ described here should prove valuable for the identification of contact sites on receptors by photoaffinity labeling experiments.
\end{abstract}

\section{Introduction}

Chemokines represent a large family of $8-10-k D a$ proinflammatory peptides that play a role in the recruitment and activation of leukocytes at sites of inflammation. ${ }^{1,2}$ Chemokine actions are mediated by cell membrane receptors predicted to have seven transmembrane segments and coupled to G-proteins. ${ }^{3}$ Recently, some of these receptors have also been shown to act as co-receptors for HIV virus entry into cells. ${ }^{4}$ To date more than 40 chemokines are known and at least 15 receptors have been characterized. Structurally, chemokines can be classified in two subgroups based on the spacing of a motif containing cysteines near the $\mathrm{N}$-terminus: the CXC chemokines in which two cysteine residues are spaced apart by one amino acid and the CC chemokines in which the two cysteines are adjacent. Most of the chemokine receptors are promiscuous, at least in vitro, in the sense that they recognize and transduce signals in response to more than one chemokine. For instance, the CCR 1 receptor is a functional receptor for, at least, the chemokines RANTES, MIP-1 $\alpha$, monocyte chemoat-

\footnotetext{
* To whom correspondence should be addressed. Tel: +41 22706 9826. Fax: +41 22794 6965. E-mail: andre.chollet@serono.com.

† Serono Pharmaceutical Research Institute.

‡ E cole Supérieure de Biotechnologie de Strasbourg

\# Present address: Institut for Medicinsk Microbiologi og Immunologi, Aarhus Universitet, Aarhus, Denmark.

$\S$ Abbreviations: HIV, human immunodeficiency virus; MIP-1 $\alpha$, macrophage inflammatory protein-1 $\alpha$; RANTES, regulated on activation normal T-cell expressed and secreted; CCR1, CC chemokine receptor 1; CCR5, CC chemokine receptor 5; BP, 4-benzoyl phenyl; Flu, 5-fluoresceinyl; CHO, Chinese hamster ovary; PBS, phosphate-buffered saline; SDS-PAGE, sodium dodecyl sulfate-polyacrylamide gel electrophoresis; amu, atomic mass unit; HA, hemaglutinin.
}

tractant peptide-2 and -3 (MCP-2, MCP-3), and MIP-5, although the sequence homology between these chemokines is low. Conversely, the chemokine MIP-1 $\alpha$ binds to and elicits a signaling response through, at least, the CCR1, CCR4, CCR5, and US28 receptors. ${ }^{2,3}$

Little is known at the molecular level about chemokine ligand recognition by receptors. F or most receptors studied so far, mutational analysis and chimeric receptor work suggests that chemokine binding determinants are broadly distributed over a large surface area including multiple domains on the extracellular face of the receptors. One exception is CCR2 for which the $\mathrm{N}$ terminal extracellular extension is both necessary and sufficient for high-affinity binding of MCP-1. ${ }^{5}$ A twosite binding model has been proposed for the interaction of chemokines with their receptors. ${ }^{6,7}$ In this model, a first interaction with the extracellular domains of the receptor controls selectivity and a second interaction with the core of the receptor triggers the activation and the signaling response. Understanding the functional relationships between these two sites as well as the identification of residues involved in the binding and activation interactions will require more experimental work.

Direct covalent attachment of photolabile ligands is a method of choice for the determination of contact sites between hormones and their receptors. Among the different photochemically reactive functional groups, the benzophenone (BP) group offers the advantages of stability to ambient light, activation at a wavelength (350 $\mathrm{nm}$ ) that does not damage proteins, and preferential insertion into $\mathrm{C}-\mathrm{H}$ bonds even in the presence of 
solvent water. ${ }^{8}$ Benzophenone probes have been used for photolabeling a variety of short to medium-size peptides binding to their cognate G-protein-coupled receptors such as substance $P, 9,10$ angiotensin $1 I, 11$ parathyroid hormone, ${ }^{12}$ secretin, ${ }^{13}$ or cholecystokinin. ${ }^{14}$ Fluorescent ligands have found many applications to study ligand-receptor interactions and for probing the mi croenvironment of binding pockets ${ }^{15-18}$ as well as for the detection of receptor expression in cells or tissues. ${ }^{19}$

Here we report the design, synthesis, and pharmacological characterization of the first photoactivatable and fluorescent analogues of the chemokine MIP-1 $\alpha$ with high affinity for the chemokine receptors CCR 1 and CCR5. We show that these reagents can be used in photoaffinity cross-linking and fluorescence techniques to label the CCR 1 and CCR5 receptors in transfected cell lines. Furthermore, these ligands should prove valuable to study the mode of recognition of the chemokine MIP-1 $\alpha$ by CCR 1 and CCR5.

\section{Experimental Section}

Materials. Benzophenone 4-isothiocyanate was purchased from Molecular Probes (Eugene, OR) and fluoresceinyl isothiocyanate was purchased from Fluka (Buchs, Switzerland). [125I]MIP- $1 \alpha$ and $\left[{ }^{125}\right.$ ] ]BP-MIP-1 $\alpha$ were prepared by Amersham (Buckinghamshire, U.K.) by oxidative $\left.{ }^{125}\right|_{2}$ labeling. Wild-type MIP-1 $\alpha$ was from PeProTech (Rocky Hill, NJ).

General Methods. HPLC of proteins was effected on a Waters (Millipore Corp.) system, model 510 pumps linked to an automated gradient controller, model $481 \mathrm{UV} / \mathrm{vis}$ detector, using a Nucleosil 300-7 C8 col umn (Macherey-Nagel ET250/ 8/4); buffer A, $0.1 \%$ (w/v) TFA/water; buffer B, $0.09 \%$ TFA/ $80 \%$ acetonitrile/water; flow rate, $1.0 \mathrm{~mL} / \mathrm{min}$; gradient, $0-75 \%$ $\mathrm{B}$ at $1 \% \mathrm{~B} / \mathrm{min}$. Proteins were detected at $214 \mathrm{~nm}$. Both BPMIP- $1 \alpha$ and Flu-MIP-1 $\alpha$ were purified by HPLC, isolated as lyophilized $\mathrm{CF}_{3} \mathrm{CO}_{2} \mathrm{H}$ salts, and quantified by amino acid analysis. They were frequently checked by analytical HPLC.

Purified proteins and their derivatives were analyzed by Edman N-terminal sequencing on an Applied Biosystem, Inc. Procise 494. For compositional amino acid analysis, about 1 nmol of protein was hydrolyzed in gas phase under vacuum for $24 \mathrm{~h}$ in $6 \mathrm{M} \mathrm{HCl}$ containing $1 \mathrm{mg} / \mathrm{mL}$ phenol at $112{ }^{\circ} \mathrm{C}$. The resultant amino acids were quantified using a Waters AccQTag chemistry and a Hewlett-Packard HP 1090 liquid chromatograph equipped with a HP 1046A fluorescence detector. Peptides were authenticated by MS (Micromass Q-TOF). Absorbance spectra were obtained using a J asco V-550 UV/ vis spectrophotometer using a bandwidth of $2 \mathrm{~nm}$ and a scanning speed of $100 \mathrm{~nm} / \mathrm{min}$. Data were collected every 0.5 $\mathrm{nm}$ (data pitch).

Synthesis of BP-MIP-1 $\alpha$. The chemokine $\Delta$ Ala'-MIP-1 $\alpha$ (A10T) was expressed in E. coli and purified as described. ${ }^{20}$ To $1.0 \mathrm{mg}$ of $\Delta \mathrm{Ala}^{1}-\mathrm{MIP}-1 \alpha(\mathrm{A} 10 \mathrm{~T})(0.125 \mu \mathrm{mol})$ in $100 \mu \mathrm{L}$ of water was added $100 \mu \mathrm{L}$ of sodium borate $(50 \mathrm{mM}, \mathrm{pH} 8.0)$ at $4{ }^{\circ} \mathrm{C}$. To this solution was added $14 \mu \mathrm{L}$ of a freshly prepared $10 \mathrm{mM}$ solution of benzophenone 4-isothiocyanate in $\mathrm{N}, \mathrm{N}$ dimethylformamide. The mixture was stirred at room temperature for $3 \mathrm{~h}$. The reaction was monitored by RP-HPLC using conditions described in General Methods. Portions of benzophenone 4-isothiocyanate $(14 \mu \mathrm{L})$ were added again at regular 2-3-h intervals until about $50 \%$ of the starting material had reacted. Attempts to push the reaction to completion resulted in the formation of di-BP and tri-BP MIP$1 \alpha$ side products. Monolabeled BP-MIP-1 $\alpha$ was purified by HPLC as described in General Methods and lyophilized to a white powder. The yield was $30 \%$ (or $60 \%$ based on recovered starting material). Edman degradation for BP-MIP-1 $\alpha$ gave the sequence $X$ LAADTPTT where $X$ is a nonnatural amino acid, whereas analysis of $\triangle \mathrm{Ala}^{1}-\mathrm{MIP}-1 \alpha(\mathrm{A} 10 \mathrm{~T})$ gave SLAADTPTT. Amino acid analysis agreed with the expected amino acid composition. MS (electrospray ionization) for BP-MIP-1 $\alpha$ : calcd $7982.6 \mathrm{amu}$, found $7982.5 \pm 0.4 \mathrm{amu}$.

Synthesis of Flu-MIP-1 $\alpha$. To $50 \mu \mathrm{L}$ of a solution of $\Delta \mathrm{Ala}^{1}-$ MIP-1 $\alpha(\mathrm{A} 10 \mathrm{~T})(1.25 \mathrm{mM})$ in water was added $100 \mu \mathrm{L}$ of sodium borate $(50 \mathrm{mM}, \mathrm{pH} 8.0)$ at $4{ }^{\circ} \mathrm{C}$. To this solution was added 3 $\mu \mathrm{L}$ of a $25 \mathrm{mM}$ solution of FITC in N,N-dimethylformamide. This represents a 1.2-fold molar excess of FITC over protein. The mixture was incubated at room temperature in the dark for $3 \mathrm{~h}$ with continuous stirring. Flu-MIP-1 $\alpha$ was purified directly from the reaction mixture by RP-HPLC under the conditions described in General Methods. Pooled fractions containing pure Flu-MIP-1 $\alpha$ were lyophilized. The yield was $62 \%$. N-Terminal sequencing gave the expected sequence XLAADTPTA, where $X$ means no amino acid detected in the first cycle consistent with the release of the FITC-Ser at the $\mathrm{N}$-terminus. Amino acid analysis of Flu-MIP-1 $\alpha$ hydrolysate was in agreement with the expected theoretical composition. MS analysis: calcd $8131.45 \mathrm{amu}$, found $8131.53 \pm 0.02 \mathrm{amu}$.

Cell Culture. Photoaffinity labeling and fluorescence experiments were performed with $\mathrm{CHO}$ cells stably transfected with the $\mathrm{N}$-terminally HA-tagged human CCRI receptor (CCR1/CHO cells) or the $\mathrm{N}$-terminally HA-tagged human CCR5 receptor (CCR5/CHO cells) at expression levels of about 15000 and 30000 receptors/cell, respectively. The HA epitope (YPYDVPYASLRS) was added to the 5 -end of the receptor CDNA by PCR and the $\mathrm{CHO}$ cell lines were obtained as described. ${ }^{23}$ The cells were cultured as monolayers in a humidified $5 \% \mathrm{CO}_{2}$ atmosphere at $37^{\circ} \mathrm{C}$, in Dul becco's MEM/ NUT mix F-12, supplemented with $10 \%$ fetal calf serum, $2 \%$ Pen-Strep, 2 mM L-glutamine. Cells were harvested at $80 \%$ confluence with PBS containing 1 mM EDTA and washed with ice-cold PBS. Membrane fractions were prepared as previously described. ${ }^{21}$

Radioligand Binding Assays. Competition binding experiments were carried out on CCR $1 / \mathrm{CHO}$ cell membrane fractions using the scintillation proximity assay (SPA) methodology with [225] ]MIP-1 $\alpha$ as a tracer ${ }^{21}$ and CCR5/CHO wholecells with [125I ] MIP-1 $\alpha$ as a tracer following published protocols. ${ }^{20}$ All determinations were performed in triplicate, and the nonspecific

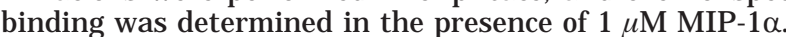

$\mathrm{Ca}^{2+}$ Mobilization Assays. Changes in intracellular $\mathrm{Ca}^{2+}$ concentration evoked by agonist stimulation were monitored spectrofluorometrically in CCR1/CHO and CCR5/CHO cells loaded with the $\mathrm{Ca}^{2+}$-sensitive dye Fura-2-AM. Cells grown in a $225-\mathrm{cm}^{2}$ flask were harvested at $80 \%$ confluence with PBS containing $1 \mathrm{mM}$ EDTA, resuspended in $15 \mathrm{~mL}$ of cell culture medium and left for $1-2 \mathrm{~h}$ at $37^{\circ} \mathrm{C}$. Cells were spun down and the medium was removed. Cells were resuspended in 10 $\mathrm{mL}$ of K rebs-Ringer medium containing $10 \mu \mathrm{g}$ of bovine serum albumin and $20 \mu \mathrm{L}$ of a $1 \mathrm{mg} / \mathrm{mL}$ solution of fluorescent $\mathrm{Ca}^{2+}$ sensitive agent Fura-2-AM (Fluka) was added. The mixture was incubated at $37^{\circ} \mathrm{C}$ in the dark for $30 \mathrm{~min}$ and then kept on ice until use. Cells were quickly spun down just before use and the medium was discarded. Cells were resuspended at 5 $\times 10^{6} \mathrm{cell} / \mathrm{s} / \mathrm{mL}$ in Krebs-Ringer buffer at $37{ }^{\circ} \mathrm{C}$. For the measurements, $0.5-\mathrm{mL}$ aliquots were transferred to a quartz cuvette under constant stirring in a J asco 777 spectrofluorometer. I rradiation was at $340 \mathrm{~nm}$ and fluorescence intensity was recorded at $505 \mathrm{~nm}$ (or $480 \mathrm{~nm}$ for assays with Flu-Mip$1 \alpha$ ). When the emission signal was stable, ligands were added in $5 \mu \mathrm{L}$. $\mathrm{Ca}^{2+}$ concentration increase was expressed in percent (\%) of maximal fluorescence intensity as determined by addition of Triton-X100. E C 50 for ligands were calculated by analysis of the data using software Grafit (E rithacus Software, Ltd.).

Photo-Cross-Linking Experiments. $\mathrm{CHO}$ cells stably transfected with either human CCR1, CCR5, or NK 1 receptors were transferred to 24 -well culture plates, $2 \times 10^{5}$ cells/well, $24 \mathrm{~h}$ before the photo-cross-linking reaction. Cells were at about $80 \%$ confluency at the time of photo-cross-linking. Cells were washed in ice-cold buffer A (50 mM HEPES, $1 \mathrm{mM} \mathrm{CaCl} 2$, $5 \mathrm{mM} \mathrm{MgCl}, 0.5 \% \mathrm{w} / \mathrm{v}$ bovine serum albumin, $\mathrm{pH} 7.2$ ) and incubated with $1 \mathrm{nM}$ [125] BP-MIP-1 $\alpha$ in buffer $\mathrm{A}$ for $4 \mathrm{~h}$ at 4 ${ }^{\circ} \mathrm{C}$. Nonspecific cross-linking was determined in the presence 
of $100 \mathrm{nM} \mathrm{MIP-1} \alpha$. Cells were irradiated on ice for $20 \mathrm{~min}$ using an UV light at $365 \mathrm{~nm}$ (Philips HPR 125W lamp) at 6-cm distance. Cells were then washed twice in ice-cold PBS, scraped off and isolated by centrifugation $(500 \mathrm{~g})$ for $15 \mathrm{~min}$ at $4{ }^{\circ} \mathrm{C}$. The cell pellet was dissolved in $40 \mu \mathrm{L}$ of $10 \%$ SDS. After removal of cell debris by centrifugation, the extract was analyzed by denaturing PAGE under reducing conditions (4$20 \%$ Tris-glycine gel from Novex, $4 \mathrm{M}$ urea, $2 \% \beta$-mercaptoethanol). Cross-linking products were revealed by autoradiography.

Immunoprecipitation. CCR $1 / \mathrm{CHO}$ cells labeled by photoaffinity with BP-MIP-1 $\alpha$ were incubated in buffer containing $300 \mathrm{mM} \mathrm{NaCl}, 2 \% \mathrm{w} / \mathrm{v} \mathrm{NP}-40,1 \% \mathrm{w} / \mathrm{v}$ deoxycholate, $0.2 \% \mathrm{w} / \mathrm{v}$ SDS in $100 \mathrm{mM}$ Tris- $\mathrm{HCl} \mathrm{pH} 7.5$, on ice for $45 \mathrm{~min}$. Cells were scraped off and centrifuged (100000g, $20 \mathrm{~min}, 4^{\circ} \mathrm{C}$ ) to remove the debris. Mouse monocl onal anti-HA antibody (12CA5 from Boehringer) and goat anti-mouse IgG magnetic beads (Dynabeads) were added and the mixture was incubated with gentle stirring overnight at $4{ }^{\circ} \mathrm{C}$. Beads were washed twice with PBS, $0.1 \%$ bovine serum albumin, and the complex was then released from the beads by incubating in 10\% SDS for $30 \mathrm{~min}$ at $20^{\circ} \mathrm{C}$.

Alternatively, the CCR $1-\mathrm{MIP}-1 \alpha$ complex was immunoprecipitated as described above using rabbit anti-MIP-1 $\alpha$ IgG (PeproTech, Inc., Rocky Hill, NJ ) and sheep anti-rabbit Dynabeads.

Fluorescence Measurements. Binding of fluorescent FluMIP-1 $1 \alpha$ to the CCR 1 or CCR5 receptors was measured on a suspension of cell membranes from stably transfected $\mathrm{CHO}$ cells expressing about 30000 receptors/cell. Membrane suspensions at a total protein concentration of $0.7 \mathrm{mg} / \mathrm{mL}$ were incubated in $50 \mathrm{mM}$ sodium Hepes, $\mathrm{pH} 7.2,1 \mathrm{mM} \mathrm{CaCl}$, 5 $\mathrm{mM} \mathrm{MgCl} 2,0.5 \%$ (w/v) BSA, $0.5 \mathrm{mM}$ sodium azide with $50 \mathrm{nM}$ Flu-MIP- $1 \alpha$ in the presence (nonspecific binding) or absence (total binding) of $17 \mu \mathrm{M} \mathrm{MIP}-1 \alpha$ at $20^{\circ} \mathrm{C}$ for $1 \mathrm{~h}$. As an additional control, membranes were also incubated in the absence of fluorescent ligand. Membranes were then washed twice with ice-cold PBS pH 7.2, resuspended in $500 \mu \mathrm{L}$ of icecold PBS and homogenized by sonication in an ice-cold bath for $3 \mathrm{~min}$ immediately prior to fluorescence measurements. Fluorescence spectra were recorded using a J asco FP-750 spectrofluorometer with a $0.5-\times 1.0-\mathrm{cm}$ quartz cuvette. During the recording of emission spectra, membrane suspensions were continuously stirred at $20^{\circ} \mathrm{C}$. Fluorescence was corrected for light scattering and background fluorescence from control samples. The excitation wavelength was $475 \mathrm{~nm}$ and the emission was recorded from 500 to $600 \mathrm{~nm}$. The spectra were generated using the following acquisition parameters: excitation and emission bandwidths, 5 and $10 \mathrm{~nm}$, respectively; data pitch, $1 \mathrm{~nm}$; scanning speed, $125 \mathrm{~nm} / \mathrm{min}$. The fluorescence measurements were made within the linear portion of the photon multiplier tube's response. Spectra were not corrected for lamp intensity or for PMT sensitivity.

For collisional quenching experiments, membrane suspensions were incubated as described above and increasing amounts of $\mathrm{KI}$ were added to a final concentration of $50 \mathrm{mM}$. Changes in fluorescence due to the addition of the quencher $\mathrm{KI}$ were corrected by subtracting the fluorescence measured in parallel control samples to account for autofluorescence quenching and dilution effects upon addition of the quencher. Typically, a complete quenching experiment was performed in about 6-8 $\mathrm{min}$. Under these conditions the contribution of fluorescence signal from dissociated ligand was negligible. As a control for ligand dissociation, samples were incubated during the times typically allocated to quenching experiments, centrifuged and the measurement repeated. No changes in the fluorescence values are indicative of negl igible dissociation of ligand. Also, we checked that the equilibrium binding of [125I ] MIP-1 $\alpha$ to either CCR 1 or CCR5 receptors was not affected by $50 \mathrm{mM} \mathrm{KI}$. The quencher stock solution was $0.153 \mathrm{M} \mathrm{KI}$ containing $1 \mathrm{mM} \mathrm{Na} \mathrm{S}_{2} \mathrm{O}_{3}$ to prevent formation of $\mathrm{I}_{3}^{-}$. The quenching of the fluorescence emission at $520 \mathrm{~nm}$ was calculated with the Stern-Volmer equation as described. ${ }^{15}$ The Stern-Volmer constant $K_{\mathrm{sv}}$ was determined from the slope of

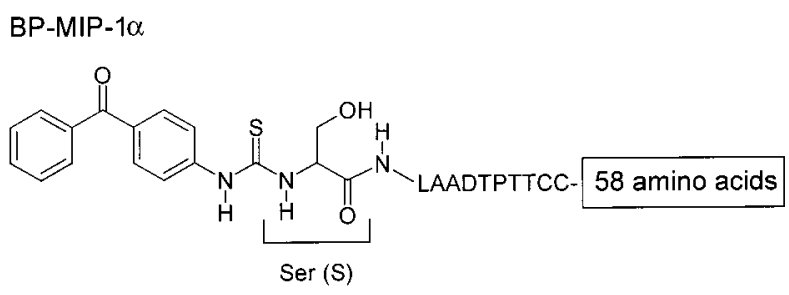

Flu-MIP-1 $\alpha$

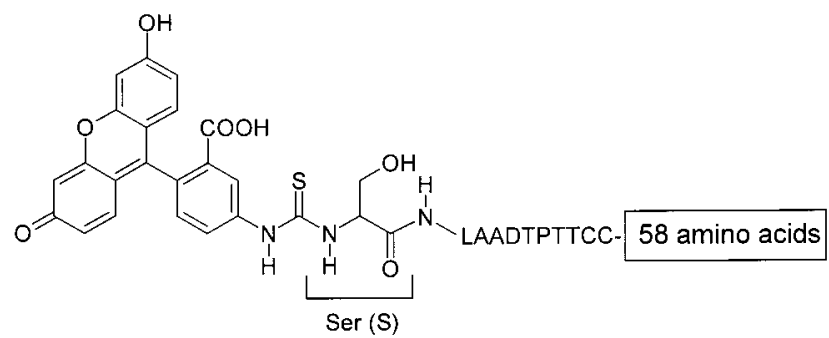

Figure 1. Structure of the MIP-1 $\alpha$ derivatives BP-MIP-1 $\alpha$ and Flu-MIP-1 $\alpha$.

the ratio of fluorescence intensities in the absence and in the presence of iodide, $\mathrm{F} d \mathrm{~F}$, as a function of the iodide concentration.

\section{Results}

Synthesis of the Photoactivatable MIP-1 $\alpha$ Analogue BP-MIP- $\alpha$. The chemokine $\Delta$ Ala $^{1}-M I P-1 \alpha(A 10 T)$, a variant of human MIP-1 $\alpha$ lacking the first amino acid Ala ${ }^{1}$ and in which Ala ${ }^{10}$ was substituted with Thr for reasons not related to this study, was derivatized with the photoactivatable benzophenone group to yield the MIP-1 $\alpha$ analogue $N-\alpha$-(4-benzoylphenyl)thi ocarbamoyl$\Delta \mathrm{Ala}^{1}-\mathrm{MIP}-1 \alpha(\mathrm{A} 10 \mathrm{~T})$ (hereafter BP-MIP-1 $\alpha$; Figure 1) as described in the Experimental Section. Under these conditions, isothiocyanate el ectrophiles react preferentially with the low $\mathrm{pK}_{\mathrm{a}} \mathrm{N}$-terminal amino group of peptides rather than with the high $\mathrm{pK}_{\mathrm{a}} \epsilon$-amino groups on lysyl side chains. ${ }^{22}$ Comparative E dman degradation of BP-MIP- $1 \alpha$ and MIP- $1 \alpha$ and analysis of the phenylthi ohydantoin derivatives at each cycle confirmed the preferential attachment of benzophenone at the $\mathrm{N}$ terminal position of MIP- $1 \alpha$. More than $95 \%$ of the benzophenone group was on the $\mathrm{N}$-terminal amine.

Synthesis of the Fluorescent MIP-1 $\alpha$ Analogue Flu-MIP-1 $\alpha$. Fluoresceinthiocarbamoyl- $\Delta$ Ala ${ }^{1}-M I P-1 \alpha-$ (A10T) (Flu-MIP-1 $\alpha$; Figure 1) was synthesized from fluorescein isothiocyanate and $\Delta \mathrm{Ala}^{1}-\mathrm{MIP}-1 \alpha(\mathrm{A} 10 \mathrm{~T})$ as described in the Experimental Section. Flu-MIP-1 $\alpha$ was labeled at $>95 \%$ on the $\mathrm{N}$-terminal amine of the peptide as determined by $\mathrm{E}$ dman sequencing.

Pharmacological Characterization of BP-MIP$1 \alpha$ and FIu-MIP-1 $\alpha$. BP-MIP- $1 \alpha$ and Flu-MIP- $1 \alpha$ were assayed for chemokine receptor binding affinity by competitive displacement binding analysis with the ${ }^{125}$ | labeled MIP-1 $\alpha$ ligand on membranes of $\mathrm{CHO}$ cells stably transfected with the CCR 1 or $\mathrm{CHO}$ cells transfected with the CCR5 receptor tagged with a HA epitope at the extreme $\mathrm{N}$-terminus (Figure 2A,B). It was shown previously that the tagged receptors retained highaffinity ligand binding and ligand specificity. ${ }^{23}$ As shown in Table 1, BP-MIP-1 $\alpha$ conserved high-nanomolar affinity at CCR1 and was even binding tighter than MIP$1 \alpha$. BP-MIP- $1 \alpha$ bound to CCR5 with $20.3 \mathrm{nM}$ affinity, comparable to wild-type MIP-1 $\alpha$ (8.9 nM) (Table 2). Flu- 


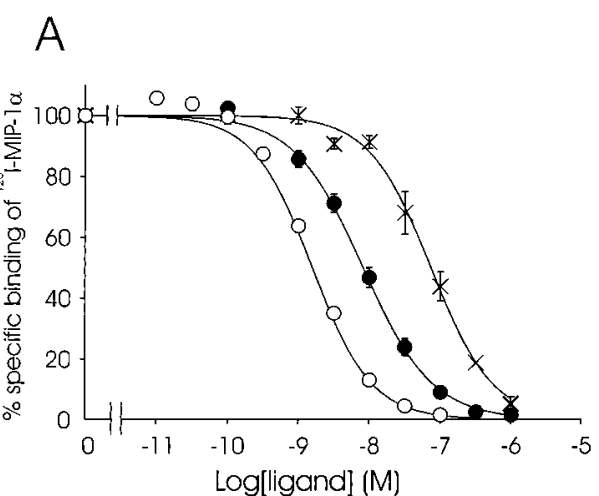

B

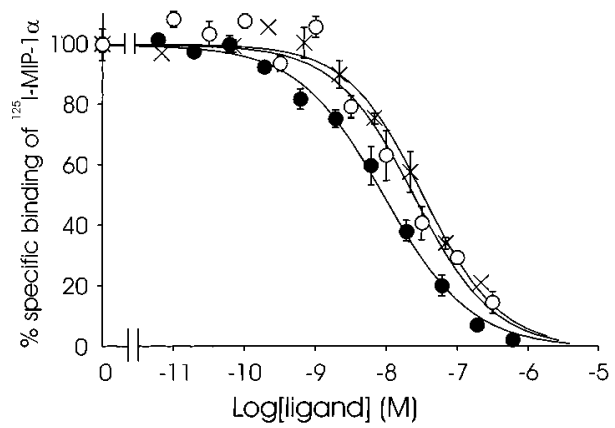

Figure 2. Competition binding experiments in human CCR1 and CCR5 receptors: (A) CCR1 receptor; (B) CCR5 receptor. Binding experiments were performed on $\mathrm{CHO}$ cell membranes for CCR1 or whole cells for CCR5 as described in the Experimental Section. Competition binding of [ $\left.{ }^{125} \mathrm{I}\right] \mathrm{MIP}-1 \alpha$ by

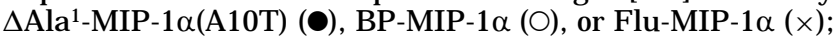
average curves (means \pm SE) of three independent experiments are shown.

Table 1. Pharmacological Constants for MIP-1 $\alpha$ Derivatives on $\mathrm{CCR} 1^{\mathrm{a}}$

\begin{tabular}{|c|c|c|c|c|}
\hline \multirow[b]{2}{*}{ ligand } & \multicolumn{2}{|c|}{ binding } & \multicolumn{2}{|c|}{$\begin{array}{l}\mathrm{Ca}^{2+} \text { mobilization } \\
\text { in } \mathrm{CHO} \text { cells }\end{array}$} \\
\hline & $\begin{array}{c}K_{i} \\
(n M)\end{array}$ & $\begin{array}{l}\text { change } \\
\text { (-fold) }\end{array}$ & $\begin{array}{l}\mathrm{EC}_{50} \\
(\mathrm{nM})\end{array}$ & $\begin{array}{l}\text { change } \\
\text { (-fold) }\end{array}$ \\
\hline $\mathrm{MIP}-1 \alpha$ & $14.0 \pm 1.1(7)$ & & $1.23 \pm 0.66(2)$ & \\
\hline$\Delta \mathrm{Ala}^{1}-\mathrm{MIP}-1 \alpha(\mathrm{A} 10 \mathrm{~T})$ & $8.50 \pm 1.19(5)$ & 0.6 & $2.11 \pm 0.53(4)$ & 1.7 \\
\hline BP-MIP-1 $\alpha$ & $1.67 \pm 0.45$ & 0.1 & $1.00 \pm 0.45$ & 0.8 \\
\hline Flu-MIP-1 $\alpha$ & $74.2 \pm 12.4(3)$ & 5.3 & $75.0 \pm 12.6$ & 61 \\
\hline
\end{tabular}

a The number of independent experiments is shown in parentheses.

Table 2. Pharmacological Constants for MIP-1 $\alpha$ Derivatives on CCR5 $^{a}$

\begin{tabular}{|c|c|c|c|c|}
\hline \multirow[b]{2}{*}{ ligand } & \multicolumn{2}{|c|}{ binding } & \multicolumn{2}{|c|}{$\begin{array}{l}\mathrm{Ca}^{2+} \text { mobilization } \\
\text { in } \mathrm{CHO} \text { cells }\end{array}$} \\
\hline & $\begin{array}{c}\mathrm{K}_{\mathrm{i}} \\
(\mathrm{nM})\end{array}$ & $\begin{array}{l}\text { change } \\
\text { (-fold) }\end{array}$ & $\begin{array}{l}\mathrm{EC}_{50} \\
(\mathrm{nM})\end{array}$ & $\begin{array}{l}\text { change } \\
\text { (-fold) }\end{array}$ \\
\hline MIP-1 $1 \alpha$ & $8.9 \pm 2.7(4)$ & & $3.5 \pm 0.9(3)$ & \\
\hline$\Delta \mathrm{Ala}^{1}-\mathrm{MIP}-1 \alpha(\mathrm{A} 10 \mathrm{~T})$ & $10.2 \pm 1.9(7)$ & 1.1 & $59.3 \pm 21.5(4)$ & 17 \\
\hline BP-MIP-1 $\alpha$ & $20.3 \pm 2.9$ & 2.3 & $60.9 \pm 31.4$ & 17 \\
\hline Flu-MIP-1 $\alpha$ & $28.1 \pm 4.5(3)$ & 3.2 & $261 \pm 24(3)$ & 83 \\
\hline
\end{tabular}

a The number of independent experiments is shown in parentheses.

MIP-1 $\alpha$ showed a 5 -fold decrease in affinity at CCR1 and a 3-fold decrease at CCR5 (Tables 1 and 2). These results indicate that replacement of $\mathrm{Ala}^{1}$ in $\mathrm{MIP}-1 \alpha$ by the more bulky benzophenone group had no significant effect on the binding affinity. However, further increase of the molecular volume at the $\mathrm{N}$-terminal position, as

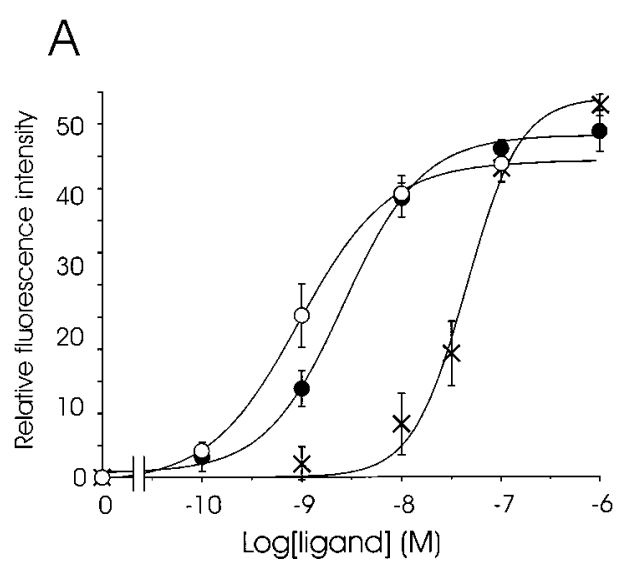

B

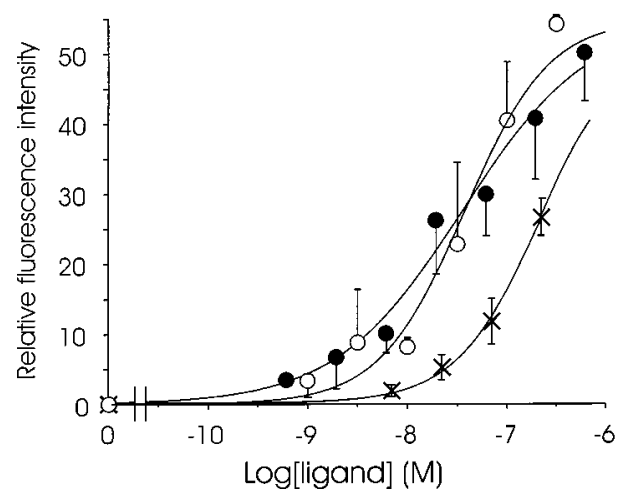

Figure 3. Biological activity of MIP-1 $\alpha$ analogues. Stimulation of CCR1 (A) and CCR5 (B) in CHO cells assayed by mobilization of intracellular calcium in response to $\triangle \mathrm{Ala}^{1}-\mathrm{MIP}$ -

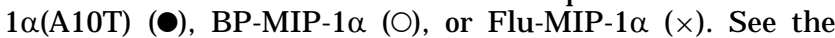
Experimental Section for details; average curves (means \pm SE) of three independent experiments are shown.

in Flu-MIP-1 $\alpha$, caused a slight decrease in receptor affinity. This can be best explained by the steric hindrance or creation of unfavorable el ectronic contacts between the fluorescein group in the receptor binding pocket.

The ability of N-terminally modified MIP-1 $\alpha$ analogues to activate either CCR 1 or CCR5 receptors was assayed spectrophotometrically by measuring the agonist-evoked increase in intracellular concentration of calcium ions in $\mathrm{CHO}$ cells loaded with the dye Fura-2. Both BP-MIP- $1 \alpha$ and Flu-MIP-1 $\alpha$ conserved full agonist efficacy at the CCR1 receptor (Figure $3 A$ ). Though the potency of BP-MIP-1 $\alpha\left(E_{50}=1 \mathrm{nM}\right)$ and wild-type MIP-1 $\alpha\left(E_{50}=1.2 \mathrm{nM}\right)$ for CCR1 were virtually identical, Flu-MIP-1 $\alpha\left(\mathrm{EC}_{50}=75 \mathrm{nM}\right)$ showed a 60 -fold decrease (Table 1). On CCR5, both N-terminally modified ligands were also full agonist albeit their potency was decreased 17-fold for BP-MIP-1 $\alpha$ and 83-fold for Flu-MIP-1 $\alpha$, respectively, as compared to wild-type MIP-1 $1 \alpha$. However this effect was much less pronounced when compared to the parent peptide $\Delta \mathrm{Ala}-\mathrm{MIP}-1 \alpha$ (Figure 3B and Table 2). Similar variations in binding interactions and agonist potency at CCR 1 and CCR5 receptors were recently reported for naturally occurring $\mathrm{N}$-terminal isoforms of MIP-1 ${ }^{26}$

Photoaffinity Labeling of CCR1 and CCR5. I rradiation at $365 \mathrm{~nm}$ of 125 -labeled BP-MIP-1 $\alpha$ bound to $\mathrm{CCR} 1 / \mathrm{CHO}$ or $\mathrm{CCR} 5 / \mathrm{CHO}$ cells produced a cross- 

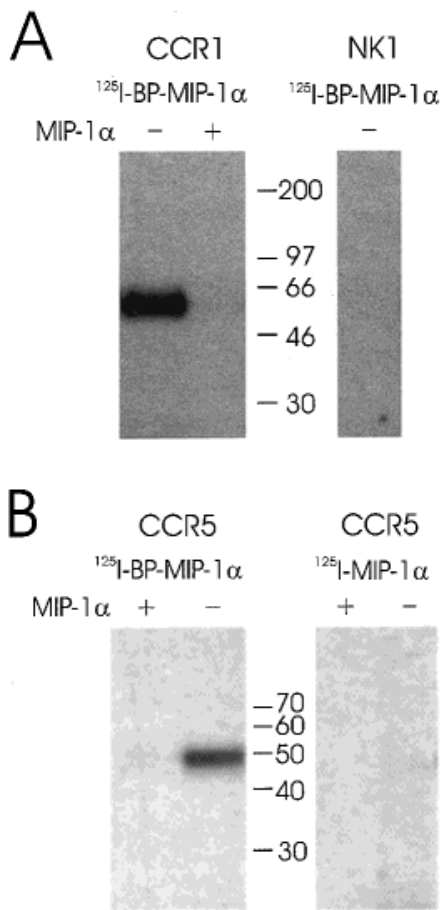

Figure 4. Photoaffinity cross-linking of $\left.\left[{ }^{125}\right]\right] B P-M I P-1 \alpha$ to CCR 1 (A) and CCR5 (B) in CHO cells. [125I ]BP-MIP-1 $\alpha$ (1 nM) was incubated with cells expressing CCR 1 or CCR 5 in the presence $(+)$ or absence $(-)$ of MIP-1 $1 \alpha(100 \mathrm{nM})$ or with cells expressing the human neurokinin NK 1 receptor, then irradiated at $365 \mathrm{~nm}$ for $20 \mathrm{~min}$ and analyzed by sizing SDS-PAGE.

linked material of apparent molecular weight 54 or 48 $\mathrm{kDa}$, respectively, on SDS-PAGE (Figure $4 A, B$ ). Several controls were carried out to ensure the specificity of photo-cross-linking. In the absence of light irradiation no product was observed. In the presence of a 100 -fold excess of MIP-1 $\alpha$ competitor ligand, no cross-link material was visible. In addition [125] ]MIP-1 $\alpha$ lacking the benzophenone group was not complexed to the chemokine receptors upon light irradiation. The photo-crosslinking was specific for CCR 1 or CCR 5 and did not occur on $\mathrm{CHO}$ cells expressing the human neurokinin NK1 receptor. The photo-cross-linking of [125I ]BP-MIP-1 $\alpha$ was rapid, did not seem to progress further after $5 \mathrm{~min}$, and was ligand concentration-dependent (Figure 5A-D). The apparent mass of $54 \mathrm{kDa}$ is consistent with a $1: 1$ adduct between MIP-1 $\alpha(8 \mathrm{kDa})$ and CCR 1 . The calculated molecular weight of HA-CCR1 is $41 \mathrm{kDa}$, but the observed apparent migration on SDS polyacrylamide gel by Western blotting with the anti-HA monoclonal antibody $12 \mathrm{CA} 5$ is $46 \mathrm{kDa}$ (data not shown). The 54$\mathrm{kDa}$ band was also observed in immunoprecipitation experiments of the covalent photoproduct with either the monoclonal antibody 12CA5, directed against the HA-tag on CCR1, or with an anti-MIP-1 $\alpha$ antibody (Figure 6). In addition, chemical cross-linking of [125| ]MIP-1 $\alpha$ to CCR1 on $\mathrm{CHO}$ cells with N-ethyl-N'-diethylaminocarbodiimi de produced an adduct migrating at 54 $\mathrm{kDa}$ (data not shown). The apparent mass of the MIP$1 \alpha-$ HA-CCR 5 cross-linking complex was $48 \mathrm{kDa}$, a value in agreement with a 1:1 chemokine-receptor adduct.

Interaction of the Fluorescent Ligand F lu-MIP$1 \alpha$ with CCR 1 and CCR5 Receptors in Cells. Membrane fractions from $\mathrm{CHO}$ cells expressing the
A

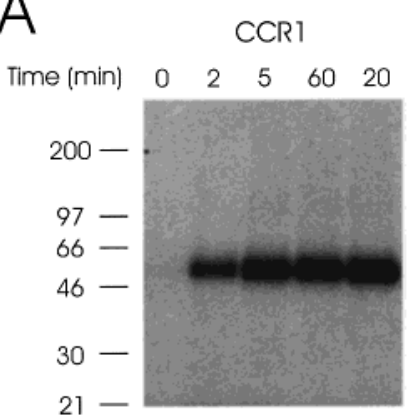

B

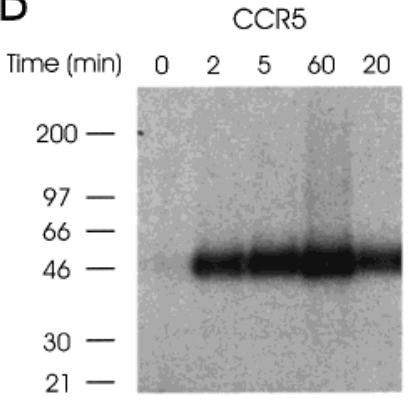

C

CCRI

Conc (pM) $500 \begin{array}{llll}525 & 31 & 8\end{array}$

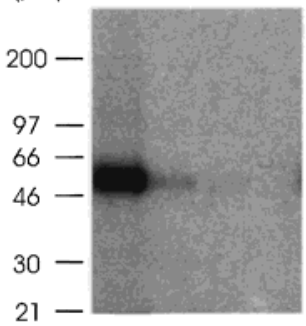

D

CCR5

Conc (pM) $500125 \quad 31 \quad 8$

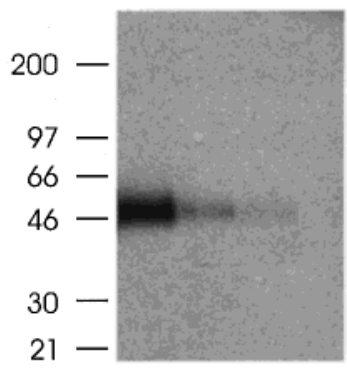

Figure 5. Time and concentration dependence of photo-crosslinking of $\left[{ }^{125}\right.$ ] B B P-MIP-1 $\alpha$ to chemokine receptors: $(A, C)$ CCR1; (B, D) CCR5. In panels A and B, the concentration of [125] ]BP-MIP-1 $\alpha$ was $0.5 \mathrm{nM}$ and the times of irradiation were as indicated. In panels $C$ and D, the time of irradiation was $20 \mathrm{~min}$ and the concentrations of [125I]BP-MIP-1 $\alpha$ were as indicated.

CCR 1 or CCR 5 receptors were specifical ly labeled with the fluorescent chemokine Flu-MIP-1 $\alpha$. Figure 7A shows the absorption and emisssion spectra. Figure 7B,C shows the total bound fluorescence $(T)$, the nonspecific bound fluorescence $(\mathrm{N})$, and the fluorescence from control membranes (C). F or both receptors the nonspecific fluorescence signal $\mathrm{N}$ represents about $28 \%$ of the total signal, giving a ratio of signal-to-noise of about 3.5. 


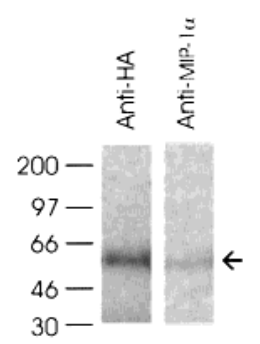

Figure 6. I mmunoprecipitation of photoaffinity-labeled CCR1 receptor. Detection of the covalent complex between [125I ]BPMIP1 $\alpha$ and HA-CCR 1 by immunoprecipitation with the antiHA monoclonal antibody 12CA5 (left lane) and with an anti MIP-1 $\alpha$ antibody (right lane).

Collisional quenching experiments were performed to probe the accessibility of the fluorescent group tagged at the $\mathrm{N}$-terminus of the bound chemokine Flu-MIP-1 $\alpha$ in the ligand-receptor complexes with either CCR 1 or CCR5. Time course measurements with excitation at $475 \mathrm{~nm}$ and emission at $522 \mathrm{~nm}$ were recorded using iodide as a quencher. Figure 8A,B shows representative traces of quenching analysis in triplicate performed in at least two independent experiments for each receptor. Quenching experiments with iodide gave similar SternVolmer constants $\left(\mathrm{K}_{\mathrm{sv}}\right)$ for the fluorescent Flu-MIP-1 $1 \alpha$ when bound to CCR 1 or CCR5 in $\mathrm{CHO}$ membranes compared to the ligand free in PBS solution. The averaged values of $\mathrm{K}_{\mathrm{sv}}$ from three independent measurements were $11.0 \pm 0.9,11.2 \pm 1.5$, and $11.9 \pm 1.9$ $\mathrm{M}^{-1}$ for Flu-MIP1 $\alpha$ free in solution, specifically bound to CCR 1, and specifically bound to CCR5, respectively. In contrast, for Flu-MIP-1 $\alpha$ nonspecifically bound to CCR5/CHO membranes a $\mathrm{K}_{\mathrm{sv}}$ val ue of $1.1 \pm 1.0 \mathrm{M}^{-1}$ was obtained (data not shown). These results strongly suggest complete accessibility of the $\mathrm{N}$-terminal site of the chemokine to the aqueous soluble quencher $\mathrm{KI}$ when the ligand is bound specifically to either CCR 1 or CCR5 receptors. In contrast, the fluoresceinyl group is buried and not accessible to the aqueous phase quencher when the ligand interacts nonspecifically with the membranes.

\section{Discussion}

MIP-1 $\alpha$ is an important CC chemokine involved in many inflammatory processes. So far, there have been very few attempts to study the interactions between the prototypic MIP-1 $\alpha$, or other chemokines in general, and their receptors at the molecular level. The little information available is inferred from site-directed mutagenesis or the construction of chimeric receptors. For either of these mutational mapping approaches, it is difficult to discriminate between direct effects on ligand binding affinity or allosteric effects on receptor folding. In this study, we have devel oped probes to map the binding site of the N-terminus of MIP-1 $1 \alpha$ to the CCR 1 and CCR5 receptors. A photoactivatable anal ogue (BP-MIP- $1 \alpha$ ) and a fluorescent analogue (FIu-MIP-1 $\alpha$ ) were designed and prepared by replacing the $\mathrm{Ala}^{1}$ residue of $\mathrm{MIP}-1 \alpha$ with the benzophenyl and fluoresceinyl functional groups, respectively. Both analogues BP-MIP-1 $\alpha$ and Flu-MIP$1 \alpha$ conserved high binding affinity and reasonable agonist potency in the calcium mobilization assay at CCR 1 and CCR5, indicating that these modi fied chemokines bind to their cognate receptors in the same mode
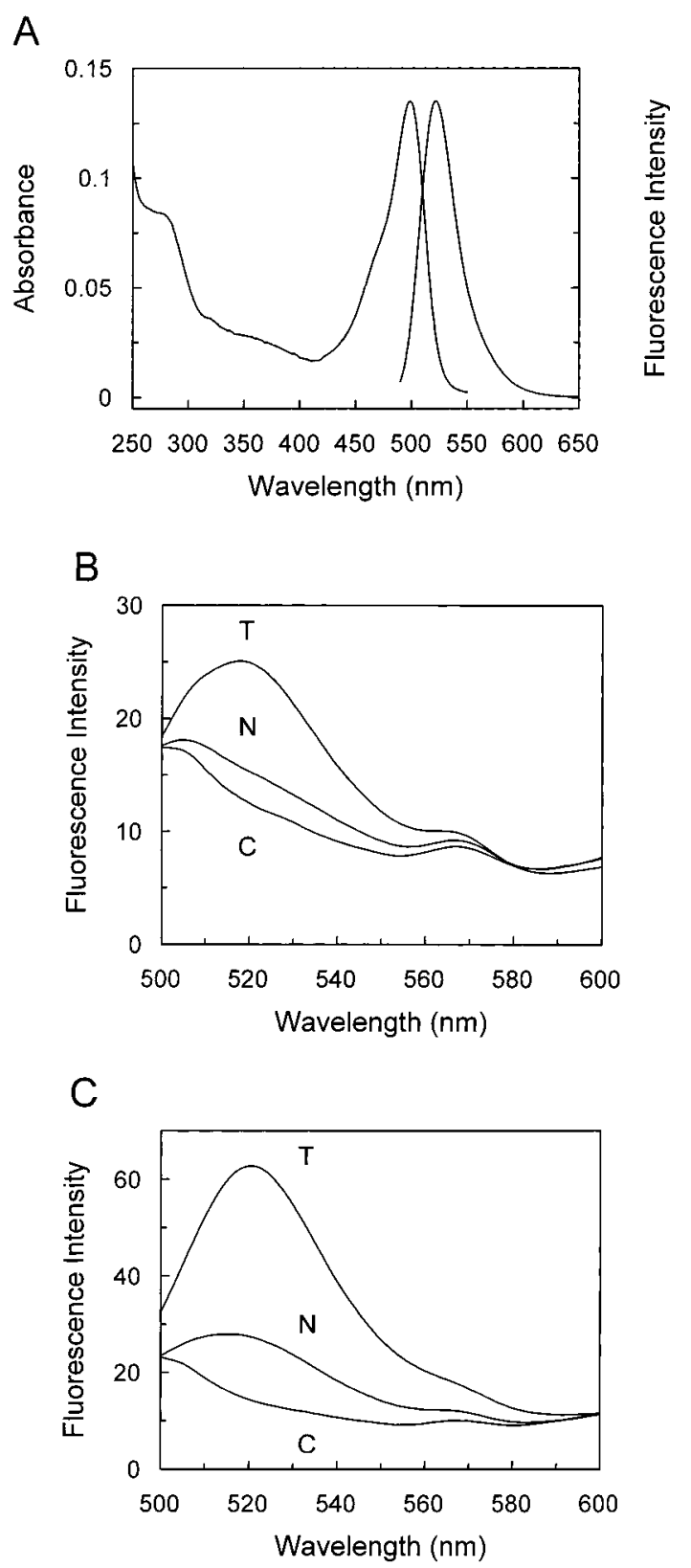

Figure 7. Fluorescence spectra of Flu-MIP-1 $\alpha$. Absorption and emission spectra of a $2.5 \mu \mathrm{M}$ solution of Flu-MIP-1 $\alpha$ in PBS are shown in panel A. Fluorescence of Flu-MIP-1 $\alpha$ bound to receptors in transfected $\mathrm{CHO}$ cell membranes is shown in panel B (CCR1) and panel C (CCR5) as total (trace T), control membranes alone (trace $\mathrm{C}$ ), and nonspecific (trace $\mathrm{N}$ ) emission spectra. See Experimental Section for details.

as the parent MIP-1 $\alpha$. Similar observations were recently published for rhodamine-MIP-1 $\alpha$ in which the fluorophore was attached specifically to the terminal amino group of the peptide chain, albeit by a different procedure. ${ }^{23}$ Also, natural isoforms of MIP-1 $\alpha$ in the $\mathrm{N}$-terminal region show subtle variations in pharmacological properties at CCR 1 and CCR5 that are best accounted for by local perturbation of ligand-receptor contacts rather than a totally different binding mode. ${ }^{26}$

Photoaffinity cross-linking of BP-MIP-1 $\alpha$ to CCR 1 stably expressed in $\mathrm{CHO}$ cells by irradiation at $365 \mathrm{~nm}$ cleanly produced a complex of apparent mol ecular mass $54 \mathrm{kDa}$ consistent with a 1:1 MIP-1 $\alpha-$ CCR 1 complex. Likewise, photo-cross-linking of BP-MIP-1 $\alpha$ to CCR5 gave a 1:1 adduct of apparent molecular mass $48 \mathrm{kDa}$. 
A

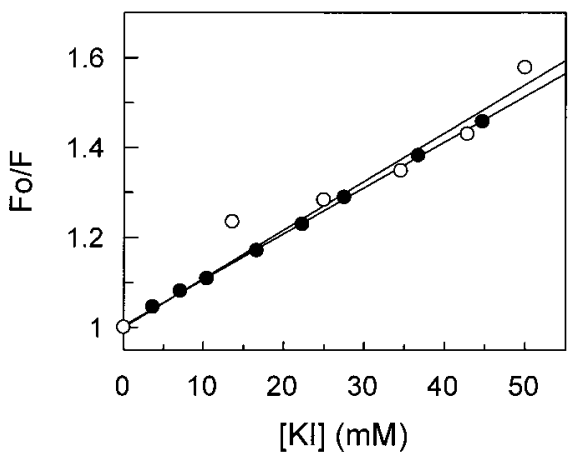

B

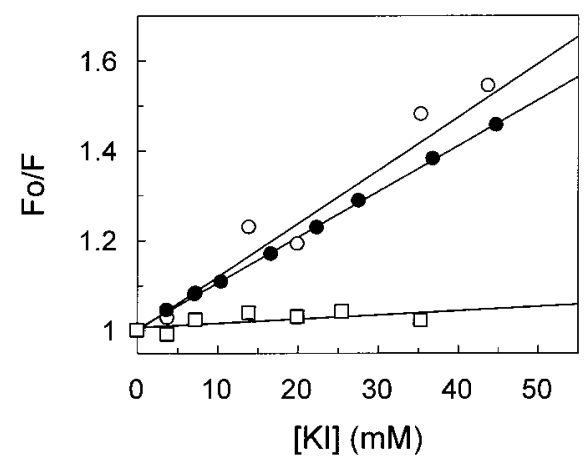

Figure 8. Collisional quenching of the receptor-bound FluMIP-1 $\alpha$ fluorescence emission by water-soluble KI. SternVolmer plots of $\mathrm{F} / \mathrm{F}$ versus quencher concentration for quenching of the fluoresceinyl fluorescence by water-soluble $\mathrm{KI}$. The Stern-Volmer quenching constants $\left(\mathrm{K}_{\mathrm{sv}}\right)$ (see text) were determined from the equation: ${ }^{24} \mathrm{~F}_{\mathrm{d}} \mathrm{F}=1+\mathrm{K}_{\mathrm{sv}}[\mathrm{Q}]$, where $\mathrm{F} d \mathrm{~F}$ is the ratio of fluorescence intensities in the absence and presence of quencher at a given concentration [Q]: (A) CCR1 receptors; $(B)$ CCR5 receptors. A representative plot of three independent experiments is shown; $\bullet=$ free in solution; $\mathrm{O}=$ specific bound; $\square=$ nonspecific bound.

For both CCR 1 and CCR5, photoaffinity labeling was dependent upon irradiation time and concentration of BP-MIP-1 $\alpha$.

The observation of covalent attachment of bound BPMIP-1 $\alpha$ indicates that the carbonyl oxygen of the benzophenone is within a distance $3.1 \AA$ of the receptor proteins. ${ }^{8}$ Thus, the $\mathrm{N}$-terminal position of bound MIP$1 \alpha$ is in close contact to the CCR 1 or CCR 5 proteins. In the future, using proteolytic digestion and amino acid or MS analysis of the ligand-receptor complexes we hope to determine contact sites at the amino acid level.

Collisional quenching of fluorescence is a powerful technique that has been used to probe solvent accessibility of receptor-bound ligands and to characterize binding pockets. ${ }^{15,16}$ The fluorescence of Flu-MIP-1 $\alpha$ bound to either CCR 1 or CCR5 was efficiently quenched by addition of increasing amounts of iodide to the solution, indicating that the N-terminal end of MIP-1 $\alpha$ was fully accessibleto the solvent in the ligand-receptor complex. We infer from these data that the $\mathrm{N}$-terminal position of bound MIP-1 $\alpha$ interacts with the extracellular domains and loops or the parts of the transmembrane helices that are at the water-membrane interface. From our results, it is unlikely that the $\mathrm{N}$-terminal of MIP-1 $\alpha$ penetrates into the hydrophobic pocket formed by the seven transmembrane helices of the receptors. We cannot totally exclude that increasing concentrations of $\mathrm{KI}$ cause conformational changes resulting in the $\mathrm{N}$-terminus of Flu-MIP-1 $\alpha$ being exposed to the aqueous environment. However, this is very unlikely as we have shown that $\mathrm{KI}$, at the concentrati ons used, does not interfere with binding of [125 ] ]MI P$1 \alpha$ at equilibrium. In the future, fluorescence energytransfer experiments may help define more accurately the position of bound MIP-1 $\alpha^{25}$

In conclusion, we have developed photoaffinity and fluorescent analogues of the chemokine MIP-1 $1 \alpha$. In the absence of high-resolution structural data for the compl exes between chemokines, or peptides in general, and their membrane receptors, the combination of biochemical analysis such as photoaffinity labeling and spectroscopic methods such as fluorescence provides valuable insights into ligand-receptor recognition patterns. The reagents described here permit to apply these methods to the important class of chemokine receptors. In particular, we showed that the N-terminal end of MIP$1 \alpha$ is in the hydrophilic environment of the extracellular parts of CCR 1 and CCR5. In the future, the unnatural amino acid benzoylphenylalanine could be iteratively incorporated into chemokines at different positions during chemical synthesis to create new probes for mapping contact sites between MIP-1 $\alpha$ or other chemokines and their cognate receptors by photoaffinity scanning. Eventually, approaches to understand the molecular basis of chemokine interactions with their receptors should help the design of chemokine antagonists to control inflammatory processes.

Acknowledgment. We thank Edith Magnenat for sequencing and amino acid analysis, Fred Borlat and Amanda Proudfoot for a generous supply of MIP-1 $\alpha$, Ronald Barrett and Erik Whitehorn for the construction of CCR1 and CCR5 cell lines, and Tim Wells and Thue Schwartz for stimulating discussions. S.Z. thanks GlaxoWellcome, plc., Stevenage, U.K., for financial support.

\section{References}

(1) Rollins, B. J . Chemokines. Blood 1997, 90, 909-928.

(2) Wells, T. N. C.; Proudfoot, A. E. I.; Power, C. A. Chemokine receptors and their role in leukocyte activation. Immunol. Lett. 1999, 65, 35-40.

(3) Premack, B. A.; Schall, T.J . Chemokine receptors: gateways to inflammation and infection. Nat. Med. 1996, 2, 1174-1178.

(4) Proudfoot, A. E. I.; Wells, T. N. C.; Clapham, P. R. Chemokine receptors - future therapeutic targets for HIV? Bi ochem. Pharmacol. 1999, 57, 451-463.

(5) Montedaro, F. S.; Charo, I. F. The amino-terminal domain of CCR2 is both necessary and sufficient for high affinity binding of monocyte chemoattractant protein 1. J . Biol. Chem. 1997, 272, 23186-23190.

(6) Siciliano, S. J .; Rollins, T. E.; DeMartino, J .; Konteakis, Z.; Malkowitz, L.; Van Riper, G.; Bondy, S.; Rosen, H.; Springer, M. S. Two-site binding of C5a by its receptor: an alternative binding paradigm for $\mathrm{G}$ protein-coupled receptors. Proc. Natl. Acad. Sci. U.S.A. 1994, 91, 1214-1218.

(7) Wells, T. N. C.; Proudfoot, A. E. I.; Power, C. A.; LustiNarashiman, M.; Alouani, S.; Hoogewerf, A.J .; Peitsch, M Methods: Companion Methods Enzymol. 1996, 10, 126-134.

(8) Dorman G.; Prestwich, G. D. Benzophenone photophores in biochemistry. Biochemistry 1994, 33, 5661-5673.

(9) Kage, R.; Leeman, S. E.; Krause, J. E.; Costello, C. E.; Boyd, N. D. I dentification of methionine as the site of covalent attachment of a p-benzoyl-phenylalanine-containing analogue of substance $P$ on the substance P (NK1) receptor. J . Biol. Chem. 1996, 271, 25797-25800

(10) Li, Y.-M.; Marnerakis, M.; Stimson, E. R.; Maggio, J . E. Mapping peptide-binding domains of the substance $P$ (NK 1) receptor from P388D 1 cells with photolabile agonists. J . Biol. Chem. 1995, 270, $1213-1220$. 
(11) Servant, G.; Laporte, S. A.; Leduc, R.; Escher, E.; Guillemette, G. Identification of angiotensin II-binding domains in the rat aT2 receptor with photolabile angiotensin analogues. J. Biol. Chem. 1997, 272, 8653-8659.

(12) Zhou, A. T.; Bessalle, R.; Bisello, A.; Nakamoto C.; Rosenblatt, M.: Suva, L. . : Chorev, M. Direct mapping of an agonist-binding domain within the parathyroid hormone/parathyroid hormonerelated protein receptor by photoaffinity cross-linking. Proc Natl. Acad. Sci. U.S.A. 1997, 94, 3644-3649.

(13) Dong, M.; Wang, Y.; Hadac, E. M.; Pinon, D. I.; Holicky, E.; Miller, L. J . Identification of an interaction between residue 6 of the natural peptide ligand and a distinct residue within the amino-terminal tail of the secretin receptor. J . Biol. Chem. 1999, 274, 19161-19167.

(14) Anders, J .; Blüggel, M.; Meyer, H. E.; ter Laak, A. M.; Kojro, E.; Fahrenholz, F. Direct identification of the agonist binding site in the human brain cholecystokinin B receptor. Biochemistry 1999, 38, 6043-6055.

(15) Turcatti, G.; Vogel, H.; Chollet, A. Probing the binding domain of the NK2 receptor with fluorescent ligands: evidence that heptapetide agonists and antagonists bind differently. Biochemistry 1995, 34, 3972-3980.

(16) Turcatti, G.; Zoffmann, S.; Lowe, J . A., III.; Drozda; S., Chassaing, G.; Schwartz, T. W.; Chollet, A. Characterization of nonpeptide antagonist and peptide agonist binding sites of the NK 1 receptor with fluorescent ligands. J. Biol. Chem. 1997, 272, 21167-21175

(17) Bradshaw, C. G.; Ceszkowski, K.; Turcatti, G.; Beresford, I. J . M.: Chollet, A. Synthesis and characterization of selective fluorescent ligands for the neurokinin NK2 receptor. J. Med. Chem. 1994, 37, 1991-1995.

(18) Vollmer, J. Y.; Alix, P.; Chollet, A.; Takeda, K.; Galzi, J . L. Subcellular compartmentalization of activation and desensitization of responses mediated by NK 2 neurokinin receptors. J . Biol. Chem. 1999, 274, 37915-37922.
(19) Durroux, T.; Peter, M.; Turcatti, G.; Chollet, A.; Balestre, M. N.; Barberis C.; Seyer, R. Fluorescent pseudo-peptide linear vasopressin antagonists: design, synthesis and applications. J . Med. Chem. 1999, 42, 1312-1319.

(20) Proudfoot, A. E. I.; Power, C. A.; Hoogewerf, A.; Montjovent M. O.; Borlat, F.; Wells, T. N. C. Characterization of the RANTES/ MIP-1a receptor (CC CKR-1) stably transfected in HEK 293 cells and the recombinant ligands. FEBS Lett. 1995, 376, 19-23.

(21) Coulin, F.; Power, C. A.; Alouani, S.; Peitsch, M. C.; Schroeder, J.-M.; Moshizuki, M.; Clark-Lewis, I.; Wells, T. N. C. Characterisation of macrophage inflammatory protein-5/human CC cytokine-2, a member of the macrophage-inflammatory-protein family of chemokines. Eur. J . Biochem. 1997, 248, 507-515.

(22) Ceszkowski, K.; Chollet, A. Synthesis of fluoresceinyl-neurokininA, a biologically active probe for NK2 receptors. Bioorg. Med. Chem. Lett. 1992, 6, 609-612.

(23) Solari, R.; Offord, R. E.; Remy, S.; Aubry, J . P.; Wells, T. N. C.; Whitehorn, E.; Oung, T.; Proudfoot, A. E. I. Receptor-mediated endocytosis of CC-chemokines. J . Biol. Chem. 1997, 272, 96179620.

(24) Lakowicz, J . R. Principles of fluorescence spectroscopy; Plenum Press: New York, 1983; pp 111-153, 258-265.

(25) Turcatti, G.; Nemeth, K.; Edgerton, M. D.; Meseth, U.; Talabot, F.; Peitsch, M.; Knowles, J .; Vogel, H.; Chollet, A. Probing the structure and function of the tachykinin neurokinin-2 receptor through biosynthetic incorporation of fluorescent amino acids at specific sites. J. Biol. Chem. 1996, 271, 19991-19998.

(26) Nibbs, R. J . B.; Yang, J .; Landau, N. R.; Mao, J .-H.; Graham, G. J. LD78 $\beta$, a nonallelic variant of human MIP-1 $\alpha$ (LD78 $\alpha$ ), has enhanced receptor interactions and potent HIV suppressive activity. J . Biol. Chem. 1999, 274, 17478-17483.

J M0009821 